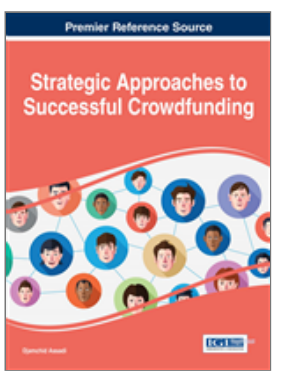

\title{
Crowdfunding as an Open Innovation for Co-Creation
}

Carmen Escudero Guirado (Comillas Pontifical University, Spain) and Carmen Goytre Castro (Comillas Pontifical University, Spain)

Copyright $\odot$ 2016. 25 pages

\section{OnDemand Chapter PDF Download}

Download link provided immediately after order completion

Current Promotions: EV 20\% Online Bookstore Discount ${ }^{\star}$

Available. Instant access upon order completion.

Source title: Strategic Approaches to Successful Crowdfunding

DOI: 10.4018/978-1-4666-9604-4.ch007 | Cite Chapter

\begin{tabular}{|l|l|l|l} 
Sample PDF & Favorite Send & Me gusta $\{+1$ & 0
\end{tabular}

\section{Abstract | Chapter Preview | Complete Chapter List}

\section{Access on Platform}

Recommend

Send to a librarian

Send to a colleague

Available In

Advances in Busines

Strategy and Competitive

Advantage

InfoSci-Books

InfoSci-Business and

Management Information

Science and Technology

Business, Administration, and

Management

\section{Browse by Subject}

Business IS\&T

Computer Science \& IT

Educational IS\&T

Engineering IS\&T

Environmental IS\&T

Library IS\&T

Media \& Communication

IS\&T

Medical \& Healthcare IS\&T

Government IS\&T

Security \& Forensic IS\&T

Social Sciences \& Online Behavior

\section{Abstract}

Crowdfunding is connected to innovation in many ways that go beyond being a new phenomenon in itself This novel model for financing projects leverages the latest technologies provided by the Internet for purposes such as the creation of online communities and electronic payments. Additionally, the existence of crowdfunding platform helps creators bring their innovative products to the market in an unprecedented manner. Crowdfunding operates as an open innovation model where the middle part of the innovation funne manner. Crowdfunding operates as an open innovation model where the middle part of the innovation funne is open to providers of funds or funders that are involved in all stages of the new product. The purpose of this more specifically, its value in co-creation. Some examples of Spanish crowdfunding platforms and innovators more specifically, its value in co-creation. Som
are analyzed to illustrate these contributions.

\section{Chapter Preview}

\section{Introduction}

It was March 25th, 2014 and the news was already in all major IT and business media: Facebook had acquired Oculus, the Virtual Reality firm, for an amount of 2 billion dollars. For decades, videogame fans had expected to improve their gaming experience by adding affordable virtual reality devices, yet none of the attempts so far had reached the combination of quality and price that Oculus offered.

What was the secret formula that allowed the Oculus founder, Palmer Luckey, to jump from his original idea to real production of the device? It was crowdfunding. Oculus started in 2012 with a successful crowdfunding campaign in Kickstarter that rose \$2.4 million from 2,750 funders and its value reached \$2 billion in less than two years.

Also in 2012, MIT Technology Review nominated crowdfunding as one of the 10 Breakthrough technologies for being An alternative to angel or venture capital investment that helps fund tech startups (Greenwalt, 2013). This was a public recognition of an emerging phenomenon that had developed in the previous years. The term was first used in August 2006 by Michael Sullivan during the launch of his failed Fundavlog project.

Crowdfunding emerged in an environment of economic crisis where the image of traditional financial institutions was tarnished. Access to financing for SME's had become increasingly difficult as a consequence of the financial crisis. Therefore, Silicon Valley Venture capitalists looked for z new ways of accessing funds. Crowdfunding was the response to this search (Best, 2013). It was the result of a convergence in time and space of peer-to-peer lending and social media. By distributing the financial risk among the crowd, it enable creators to turn their projects into reality in an unprecedented manner.

Crowdfunding is attracting attention for its $460 \%$ growth between 2010 and 2013 (Massolution, 2013) although its $\$ 5$ billion volume estimated for 2013 is still far from the $\$ 30$ billion of venture capital financing in the same period. However at the present rate of increase, crowdfunding could bypass venture capital in some years by following a pattern than resembles new entrants when disrupting an industry.

From the financial perspective, crowdfunding implies a shift in the risk profile of projects, from a large risk for one (financial institution), to numerous small risks for many (the crowd). This activity can be considered "shadow banking" since it is conducted by non-bank financial intermediaries, and represents the last step in the strategy of technology companies to compete for the financial services market: i.e. Paypal, Google, Apple and Facebook.

It is also important to acknowledge the significance of crowdfunding as part of a wider trend that includes concepts such as product co-creation, social capital development and collaborative consumption. All these movements have economic and social affairs and promote disintermediation (i.e. Uber, the transport company, has attracted great attention recently for its disintermediation potential in the taxi business)

The research inquiry of this chapter can be formulated in the following way: what is the contribution of crowdfunding to date in open innovation processes and, more specifically, what value does it bring to cocreation? Special attention is given to the Spanish case in order to identify and quantify these contributions.

The structure of this chapter is as follows: it starts with the concept of open innovation and its contribution to co-creation (Section one). This section includes a description of this new innovation paradigm and its thre types and the specification of how type 3 or co-creation contributes to innovation. Section two presents an overview of the origin and importance of crowdfunding. In this section, we analyze how the "rewards" compensation of the crowdfunding model is the one that best captures the essence of crowdfunding activity. We then present tests of product acceptance, lessons from unsuccessful campaigns and iterative innovation cases to show the contribution of crowdfunding to co-creation followed by examples from the US as the mos developed crowdfunding market Section three includes an illustration of the model and its application to the Spanish case. This chapter ends with a section drawing conclusions and suggesting opportunities for future research.

\section{Complete Book}

$\$ 205.00-\$ 310.00$

View Book Pricing Options

InfoSci"-onDemand

Full-text search over 86,600 research articles and chapters.

Full text search term(s)

Related Chapters

Financial Market Infrastructures

(2) 2016, $19 \mathrm{pp}$

The role of Financial Market nfrastructures in... () $2016,21 \mathrm{pp}$.

Regulating Global FMIs (c) 2016, $30 \mathrm{pp}$.

FMls - Knights in Shining Armour?

Exploiting Parallelization to Increase the. C) 2016, $11 \mathrm{pp}$ Using FMI Transaction Data in Simulations

A Multi-Layer Network of the Colombian Sovereign... 2016, $26 \mathrm{pp}$

More Business \& Management Titles 


\section{Complete Chapter List}

Search this Book: Full text search term(s)

Reset

\begin{tabular}{lc}
\hline Table of Contents & View Full PDF \\
\hline Preface & View Full PDF \\
\hline Acknowledgment & View Full PDF \\
\hline
\end{tabular}

Chapter 1

$\$ 30.00$

In Search of Crowdfunding Business Models (pages 1-33)

List Price: $\$ 37.50$

Djamchid Assadi

Sample PDF

Chapter 2

$\$ 30.00$

Intermediating Crowdfunding: A Foundational Assessment (pages 34-55)

Joan MacLeod Heminway

Sample PDF

Chapter 3

$\$ 30.00$

To Lend or Not to Lend: Exploring the Early Days of Peer-to-Peer Lending to Small

Businesses (pages 56-77)

Traci L. Mach, Courtney M. Carter, Cailin R. Slattery

Sample PDF

Chapter 4

$\$ 30.00$

How do the Crowdfunders Judge the Crowdfunded?: Crowdfunding, Social Capital, and List Price: $\$ 37.50$ the Gatekeepers of the Financial Legitimacy (pages 78-107)

Mathieu-Claude Chaboud

Sample PDF

Chapter 5

$\$ 30.00$

Toward a Typology of Crowdfunding Motivations (pages 108-128)

List Price: $\$ 37.50$

Leela Vedantam

Sample PDF

\section{Chapter 6}

$\$ 30.00$

Proactive Law as Competitive Advantage in Crowdfunding (pages 129-149)

Jack Wroldsen

Sample PDF

\section{Chapter 7}

$\$ 30.00$

Crowdfunding as an Open Innovation for Co-Creation (pages 150-174)

Carmen Escudero Guirado, Carmen Goytre Castro

Sample PDF

Chapter 8

$\$ 30.00$

Basic Types of Project Initiators: Contributor Relations in Platform-Based Online

Crowdfunding (pages 175-189)

Javier Vidal-García, Marta Vidal

Sample PDF

Chapter 9

Exploring the Spheres of Crowdfunding (pages 190-209)

Bernard Owens Imarhiagbe

Sample PDF

Chapter 10

$\$ 30.00$

Can Social Dynamics Be Channeled from Offline to Online Communities?: Commitment, List Price: $\$ 37.50$ Compliance, and Cooperation from Microfinance to Crowdfunding (pages 210-227)

Sharam Alijani, Djamchid Assadi, Arvind Ashta

Sample PDF

Chapter 11

Does Crowdfunding (Creatively) Disturb the Conventional (Banking) Alliances with List Price: $\$ 37.50$ Support Networks for Financing (Micro-)Entrepreneurs? (pages 228-249)

Nathalie Mercier, Hayyan Alia, Arvind Ashta, Maaouia Ben Nasr, Mihaela Bonescu, Ahmadou Bamba Ndiaye

Sample PDF

Sample PDF 
Chapter 13

$\$ 30.00$

Can Crowdfunding Provide a Solution for the Financial Problems of SMEs in Turkey? (pages 270-284)

Beyza Oba

Sample PDF

Chapter 14

$\$ 30.00$

Crowdfunding and Slow Money: Challengers or Partners - A Field Perspective (pages List Price: $\$ 37.50$ 285-294)

Jung Aymeric

Sample PDF

Chapter 15

Separating the Wheat from the Chaff: Sharing vs. Self-Interest in Crowdfunding (pages List Price: $\$ 37.50$ 295-313)

Marlyne Sahakian, Jean-Michel Servet

Sample PDF

Chapter 16

$\$ 30.00$

Do the Social Web 2.0 Media Foster Democratization? (pages 314-330)

List Price: $\$ 37.50$

Rasoul Namazi

Sample PDF

About the Contributors

Index
LEARN MORE:

About IGI Global | Contact | Careers | FAQ | Staff

RESOURCES FOR:

Librarians | Authors/Editors | Distributors | Instructors | Translators | Copy Editing Services

MEDIA CENTER:

Online Symposium | Blogs | Catalogs | Newsletters

POLICIES:

Privacy Policy | Content Reuse Policy | Ethics and Malpractice

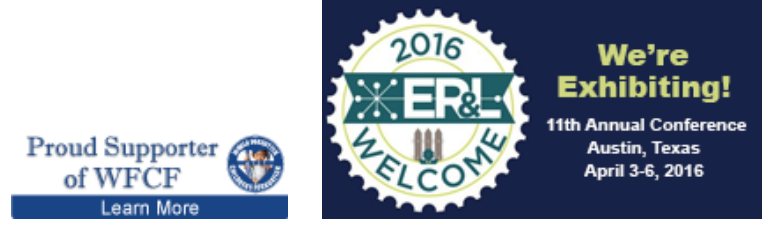

Copyright ( ) 1988-2016, IGI Global - All Rights Reserved

130.206 .72 .64 